\title{
New historical data for assets and liabilities in the UK
}

\section{SUMMARY}

This article presents the full series of UK financial accounts since 1979 for all sectors and since 1957 for households. The definition of new standards for financial accounts, and specifically SNA 93, had entailed an interruption in official time series. The article highlights the methodology used to ensure consistency in the connection between the old and the new series.

A first historical analysis of the UK data and a set of international comparisons for two of the countries (the United States and Italy) for which long-term consistent statistics are available is also provided. he main scope of this article ${ }^{1}$ is to present a reconstruction of historic financial accounts for the UK, to explore their structure and compare them with those of other selected countries.

This reconstruction has been conducted jointly with the Office for National Statistics (ONS) and the Bank of England, and is part of a broader Organisation for Economic Co-operation and Development (OECD) project to extend back the currently available time series for financial accounts for a group of OECD countries: Canada, France, Germany, Italy, Japan, Spain, the UK and the US.

Financial balance sheets were published by the Central Statistical Office (CSO $)^{2}$ and the Bank of England prior to 1987, but they were based on a different classification.

These data have never been correlated with more recent time series; this project aims to fill that gap.

Although as an initial step the OECD project focused on household and nonfinancial corporations, in the case of the UK it was decided to analyse all institutional sectors to obtain a broader picture of the UK National Accounts. The emphasis is on stocks and their impact on assets and liabilities from 1979 onwards, and on the household sector from the 1950s.

Historical data are critical for understanding macroeconomic behaviour. Longer time series allow a closer analysis of several important issues such as the evolution of financial wealth over time, trends in debt, relationships between the institutional sectors and the correlation or convergence between different countries.

The article is organised as follows.
The first section presents the general methodology and the sources of financial accounts used to reconstruct UK balance sheets for all institutional sectors. In the next section, a preliminary analysis of the evolution of household financial assets and liabilities in the UK from 1957 onwards is outlined. The following section compares the UK financial structure with that of other countries and the final section presents a summary of first conclusions. A statistical annex (available in the web version of this article at www.statistics.gov.uk/cci/ article.asp?id=1613) tabulates provisional data by sector for financial instrument assets and liabilities in the UK, from 1979 to 2006 .

\section{Sources and methodology}

For reconstruction purposes, the currently available time series from ONS (based on the SNA 93 classification), which covers the period 1987 to 2007, was used. Financial balance sheet ${ }^{3}$ figures were obtained for the period 1975 to 1987 from the Blue Book annual National Accounts.

A similar exercise was attempted for the other countries included in the OECD project, extending the time series back from 1979 for stocks (asset and liabilities) and for the following financial instruments $(\mathrm{F})$ :

F total financial assets and liabilities

F2 currency and deposits

F3 securities other than shares

F4 loans

F5 shares and other equity

F6 insurance technical reserves

F7 others 
As mentioned above, while the OECD project concentrated exclusively on the household and non-financial corporation sectors, in order to get a complete picture of UK national wealth, the reconstruction exercise included all the main institutional sectors: households, non-financial corporations, financial corporations, government and the rest of the world.

By superimposing data from the old and new time series for a number of years (1987 to 1996), it was possible to check the consistency of the reconstruction. The next section presents the outcome of this analysis.

\section{SNA 93 versus the old CSO time series}

The introduction of SNA 93 in the 1990s with its new classifications made it necessary to reconcile past data with the more recent time series. The changes concerned the definition of the sectors, the breakdown of financial instruments and the method used for valuation of the various instruments.

No significant differences were found regarding the sectors or the valuation method. The main impact of the new classification concerns the breakdown of securities.

In order to match the data from the two sources, a conversion table was constructed (see Appendix) which provides a good degree of correspondence of financial assets and liabilities over time.

However, unambiguous correspondence between the two classifications is impossible to achieve. For instance, it is difficult to find a clean split between 'securities other than shares' and 'shares and other equity', or between 'loans' and 'securities other than shares.

To try and arrive at an accurate breakdown of the instruments under the new classification, reference was made to the overlapping period between the two series, consistent with the long term trends. When these assumptions were insufficient to obtain the desired split, the strong assumption was made that the asset mix was the same as that observed in 1987. This approach follows that used by the Bank of Italy in reconstructing Italian financial balance sheets, where a specific breakdown of instruments is not available.

The reconstruction of the institutional sectors gave good results for all of them as regards total assets and liabilities. This is consistent with the hypothesis that there are no important changes in intra-sector classifications. However, when looking in more detail at the individual sectors, significant discrepancies between the two time series were found.

\section{Households ${ }^{4}$}

In the special case of the household sector, given the minor role that 'loans' and 'securities other than shares' play in the household portfolio, the strong assumption was made that all unambiguous items could be attributed to 'shares and other equity' under the new classification. This assumption was tested in the overlapping period and obtained a high degree of accuracy, confirmed by the perfect match between the old and new time series for assets and liabilities for each item. In the reconstruction, the long-term trend was managed to be maintained, allowing analysis of this and the asset mix over time.

\section{Non-financial corporations}

In order to preserve the same sector definition, public non-financial corporations were included under nonfinancial corporations as required by SNA 93, and not under government as in the previous classification.

Asset allocations in the old and new time series were then looked at. In the case of non-financial corporations, the two classifications presented discrepancies between 'loans' and 'shares and other equities. This problem was overcome by trying to reallocate the unambiguous items for the period 1979 to 1987 in the same proportions as observed in 1987.

With regard to instruments, it is worth noting that the item 'insurance and pension technical reserves' does not appear in the old Blue Book time series for the sector S11. The amount, albeit negligible, is present in the new ONS time series.

\section{Financial corporations}

This sector includes banks, building societies, pension funds, life insurance companies and other financial institutions. In the reconstruction exercise, the main problem encountered was that the amount for 'currency and deposits' was underestimated. The unambiguous 'miscellaneous instruments' was therefore attributed to this class.

The biggest discrepancies were found in liabilities after attributing all unambiguous assets to 'securities other than shares'.

A gap was also found in 'loans', which appear to be overestimated in the old classification as compared with the new.

\section{Government}

As seen above, to preserve the SNA 93 sector definitions, public non-financial corporations were moved to non-financial corporations.

Significant discrepancies appeared in assets and liabilities once all unambiguous assets had been attributed to 'loans', to match long-term trends in the financial asset mix for the sector.

\section{Rest of the world}

In the overseas sector, a good degree of continuity was found for all instruments, with one overestimation in the case of 'shares and other equity'.

In the case of overseas liabilities, after the matching exercise, a key difference was noticed in the items 'currency and deposits and loans. Once again it was decided to adjust the discrepancy by maintaining the same proportion between the two items as observed during the overlapping period.

As hinted above, the main focus in this project is the household sector. Given the fair degree of continuity in household data, it was decided to extend the time series back to 1957. The following section presents the trend in assets and liabilities and the asset mix over the last 50 years.

\section{Household wealth in the last 50 years}

\section{Previous work}

Pioneering work on UK balance sheets was presented in a book by Professor Jack Revell. This work was later extended by Revell and Roe, with the support of CSO and the Bank of England, to include annual estimates for the period 1957 to 1966 , and a summary was published in Economic Trends in 1971. Balance sheet estimates for the household sector for 1966 to 1975 were published by CSO in January 1978 and subsequently updated to 1978 . Economic Trends in 1980 included a further reconstruction of household sector data.

To get a complete picture of behaviour over the entire 50 years, these statistics were matched with the estimates described in the previous section. Matching the series for 1957 to 1978 to those for 1979 to 2006 presented none of the problems mentioned earlier, since the classifications adopted by CSO for 1966 to 1978 and by the Department of Applied Economics, Cambridge, for 1957 to 1966 were identical to those of SNA 93. No discrepancies were found between the different time series either for the asset mix or in the absolute amounts. 
Table 1

Trends in financial wealth and its distribution

\begin{tabular}{|c|c|c|c|c|c|c|c|c|c|c|c|c|c|c|c|c|c|c|c|}
\hline & & & & & & & & & & & & & & & & & & & nillion \\
\hline & \multicolumn{8}{|c|}{ CSO estimates } & \multicolumn{3}{|c|}{ OECD estimation } & \multicolumn{8}{|c|}{ Current ONS data } \\
\hline & 1957 & 1960 & 1963 & 1966 & 1969 & 1972 & 1975 & 1978 & 1979 & 1982 & 1984 & 1987 & 1990 & 1993 & 1996 & 1999 & 2002 & 2005 & 2006 \\
\hline Total financial assets & 43 & 58 & 70 & 73 & 91 & 127 & 140 & 205 & 251 & 413 & 568 & 840 & 1,191 & 1,755 & 2,078 & 3,126 & 2,681 & 3,591 & 3,846 \\
\hline Currency and deposits & 14 & 17 & 19 & 25 & 30 & 41 & 58 & 85 & 99 & 149 & 188 & 250 & 360 & 423 & 494 & 601 & 731 & 921 & 997 \\
\hline Securities other than shares & 4 & 4 & 5 & 5 & 5 & 7 & 8 & 12 & 18 & 25 & 25 & 24 & 21 & 33 & 41 & 47 & 46 & 43 & 35 \\
\hline Shares and other equities & 11 & 20 & 23 & 21 & 29 & 42 & 27 & 33 & 33 & 50 & 73 & 135 & 221 & 335 & 401 & 733 & 393 & 586 & 590 \\
\hline Insurance technical reserves & 10 & 13 & 16 & 15 & 20 & 29 & 34 & 61 & 82 & 162 & 246 & 389 & 530 & 896 & 1,069 & 1,663 & 1,419 & 1,932 & 2,111 \\
\hline Other accounts receivable and loans & s 4 & 5 & 5 & 7 & 8 & 9 & 13 & 15 & 20 & 26 & 36 & 42 & 59 & 68 & 73 & 83 & 91 & 109 & 113 \\
\hline Total financial liabilities & 7 & 10 & 12 & 15 & 18 & 28 & 39 & 59 & 79 & 127 & 180 & 270 & 419 & 485 & 550 & 675 & 923 & 1,249 & 1,371 \\
\hline
\end{tabular}

\section{Figure 1}

\section{Financial assets and liabilities as a percentage of GDP and in per capita terms}

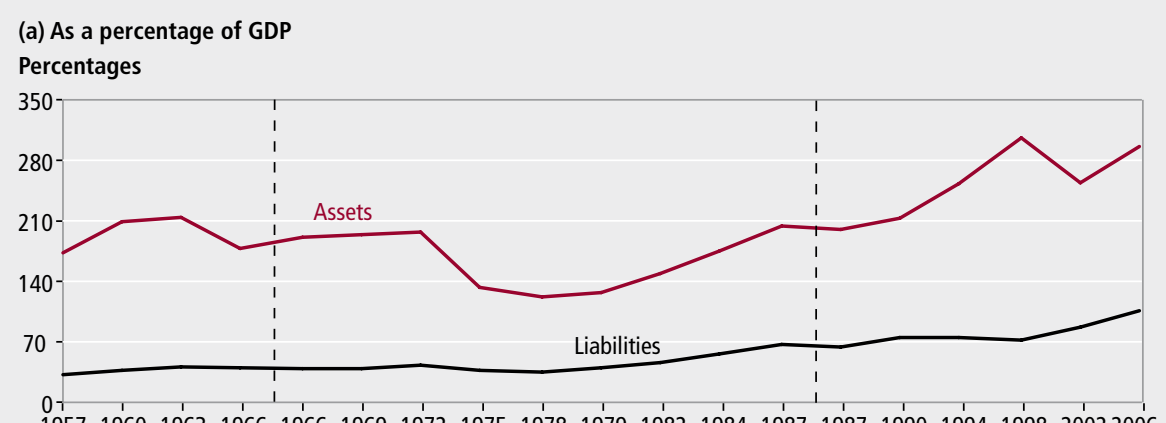

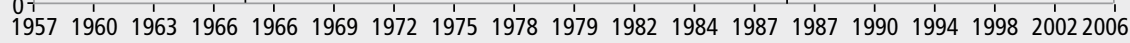

(b) Per capita

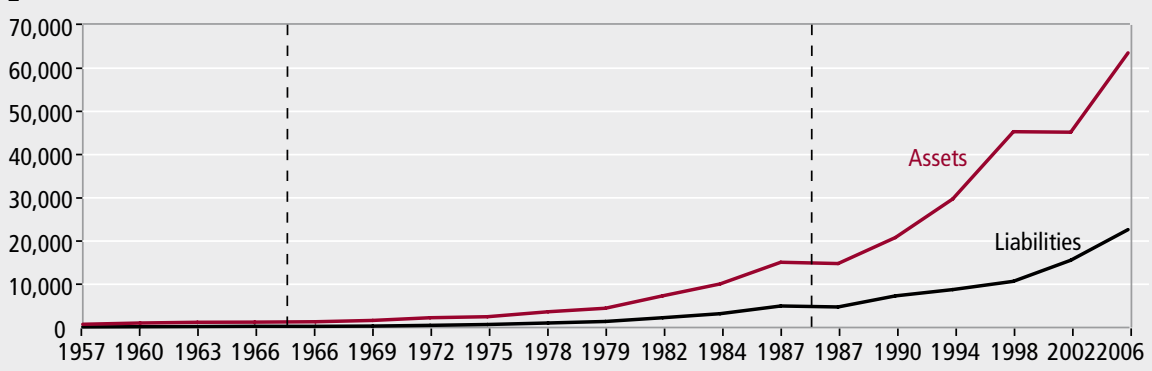

1957196019631966196619691972197519781979198219841987198719901994199820022006

\section{Figure 2}

\section{Household sector asset mix}

\section{Percentages}

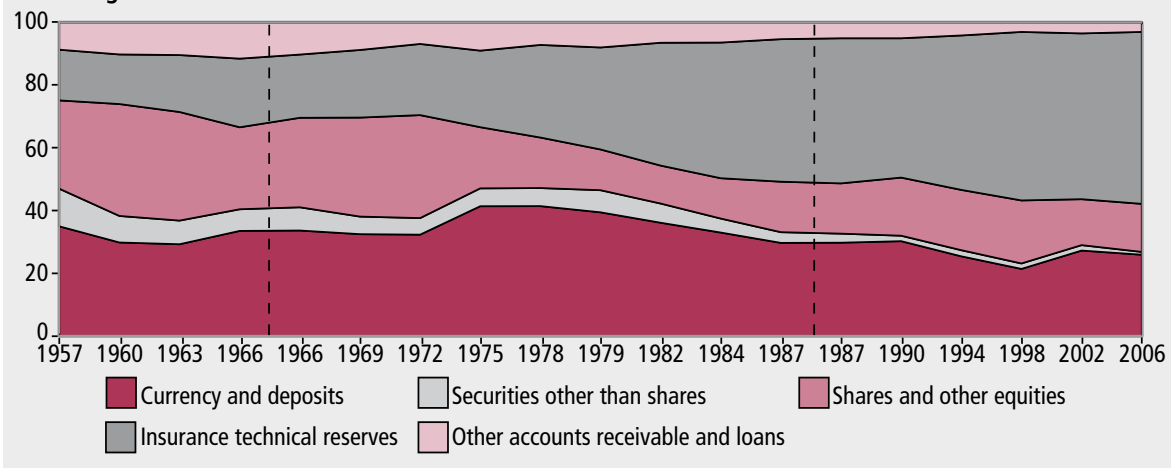

Trends in financial wealth and its distribution

Longer time series give a better insight into wealth, its allocation and dynamics within the economy (Table 1).

Important developments in the household sector can be seen over the past 50 years, both in absolute values and in the asset mix.

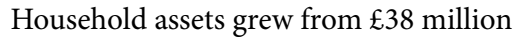
in 1957 to around $£ 3,800$ million in 2006 , a compound annual growth rate of 10 per cent. Liabilities grew by an annual 11 per cent, peaking at 17 per cent over the 1979 to 1987 period. Financial wealth as a percentage of gross domestic product (GDP) increased over the entire period, though not uniformly so (Figure 1). Three main phases can be identified:

- during the first 20 years, the ratio of financial assets to GDP remained fairly steady, averaging around 200 per cent

- during the second period, from 1972 to 1979 , a strong rise in nominal GDP not matched by a comparable increase in household assets as seen. The ratio reached a low of 122 per cent in 1979

- since the 1980s, the ratio has risen increasingly rapidly, with the sole exception of 2001

Financial wealth also increased throughout the entire period in per capita terms, though again not uniformly.

Up to the 1980s, the rising trend in financial assets remained rather stable, turning upwards more steeply only in the early 1990s, presumably as a result of the strengthening of the financial system and the liberalisation of capital movements.

As liabilities grew at around the same pace as assets, the trend for net financial wealth was similar.

The household asset mix saw considerable change during the period under review.

As can be seen in Figure 2, UK households in the 1950s had a welldiversified portfolio, though 'currency and deposits' and 'shares and other equity' clearly play the dominant role. In both cases, however, the absolute amounts were negligible. By the end of the 1960s, the most striking feature is the reduction in the weight of 'shares and other equity', a trend which was to continue further in following years. Beginning in the 1980 s, a rise in 'insurance and technical reserves' started to be witnessed, which continued to grow over 


\section{Figure 3}

\section{The household sector versus other institutional sectors}

\section{(a) Financial assets by sector}

\section{Percentages}

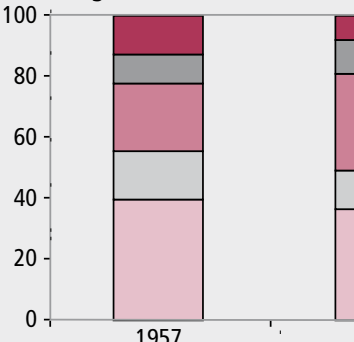

1957
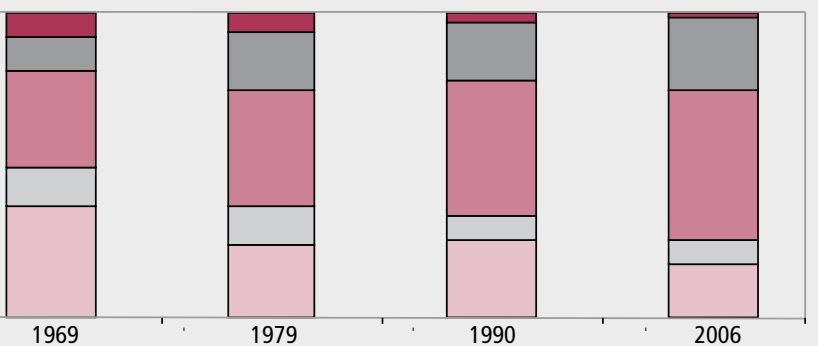

(b) Liabilities by sector

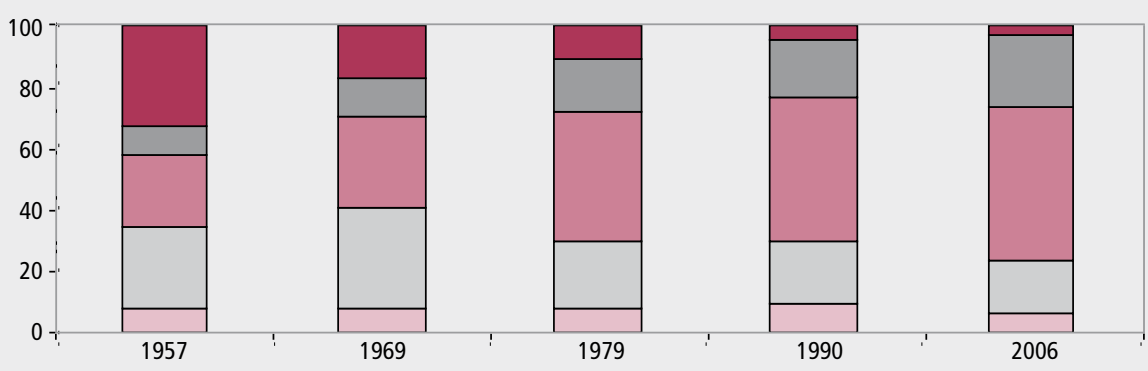

(c) Excess/deficiency of financial assets and liabilities

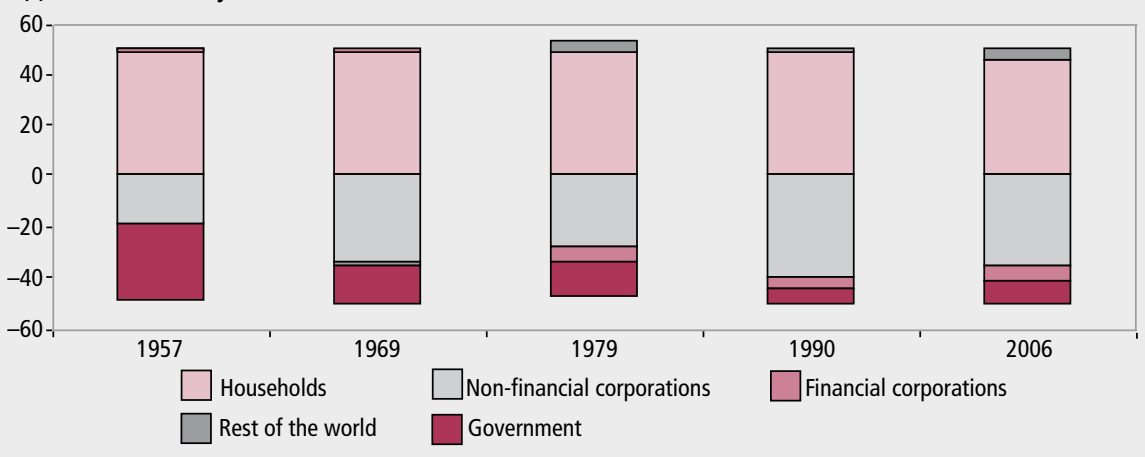

Figure 4

Household financial assets as a percentage of GDP

Percentages

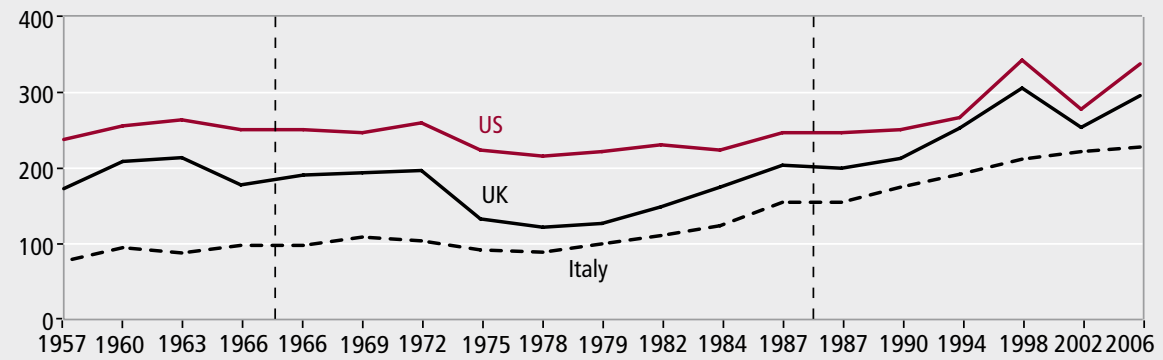

subsequent decades to become the biggest component of the mix, from around 33 per cent in the 1980 s to more than half of household portfolios in 2006.

This reflects the growth in life insurance and private pension funds complementary to social security schemes. This dominance of long-term instruments is the main peculiarity of the UK household portfolio the household portfolio shrank over the period from 32 per cent in 1979 to 15 per cent in 2006, while 'securities other than shares' fell from 12 per cent to 1 per cent.

Thus, the macro-trends in the asset mix can be summed up as follows:

- a rapid increase in the weight of life insurance and pension funds

- a substantial decrease in the direct holding of shares and securities

- a substantial fall in the share of safe assets (currency and deposits)

Positive net financial flows for the household sector

Figure 3 shows the trends in the distribution of national financial assets and liabilities over time.

Examination of national financial wealth by sector reveals a clear fall in the relative size of the household sector for both assets and liabilities, in favour of the overseas sector and financial corporations. At the same time, however, huge net financial flows mainly towards households can be seen. The majority of the corporate sector's liabilities are to the personal sector. The net financial position of the overseas sector is negative in the first decade, implying that UK holdings of overseas assets exceeded overseas holdings of UK assets, whereas the last 25 years have seen this trend reverse.

\section{International comparisons}

The peculiarities of the UK financial structure become evident when compared with other economies. In this section, the macro-trends in household financial wealth for the UK, the US and Italy are illustrated, using the UK data presented above and data provided by the OECD.stat data set for the US. For Italy, data published by the Bank of Italy (Bonci and Coletta 2005) are used.

Trends in household financial assets: UK versus US and Italy

The trends in household wealth over the last 50 years are examined first (Figure 4). Total financial assets as a percentage of GDP appear to have increased only moderately between 1960 and 1970. The trend began to rise during the period 1970 to 1980 , but the first signs of faster growth become evident only from 1995, and mainly in the UK and US. Most assets in this period benefited from the stock market boom, but were hit by the slowdown that followed before regaining strength with the recent positive performance of the markets. 


\section{Figure 5}

\section{Household financial asset mix \\ Percentages \\ (a) UK}
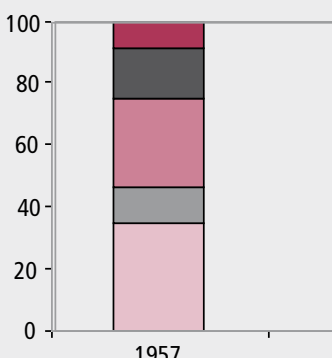

1957
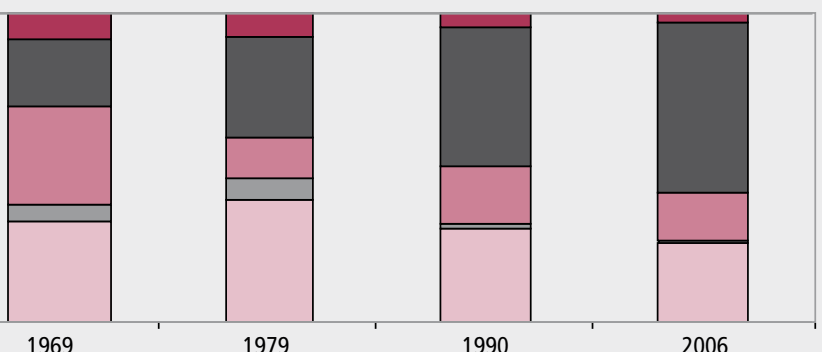

(b) US

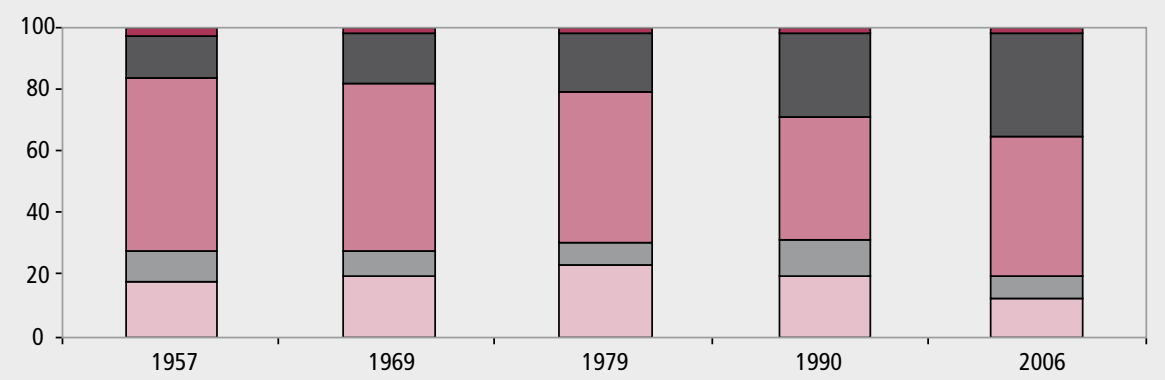

\section{(c) Italy}
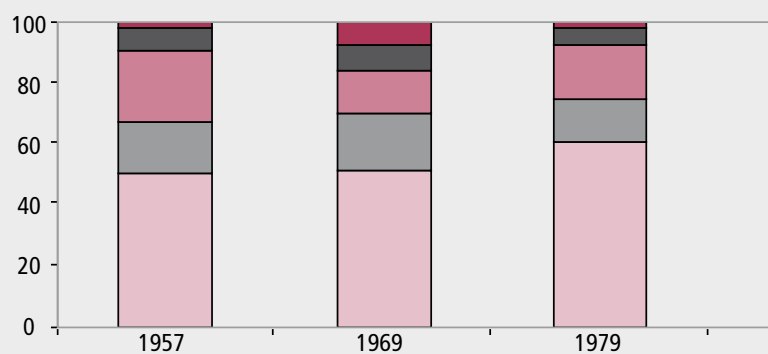

Currency and deposits

69

Securities other than shares

Other accounts receivable and loans

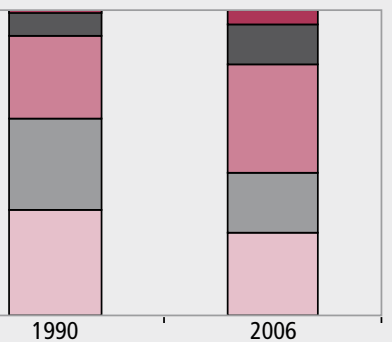

Insurance technical reserves

\section{$\square$}

Shares and other equities

\section{Figure 6 \\ Household financial liabilities as a percentage of GDP}

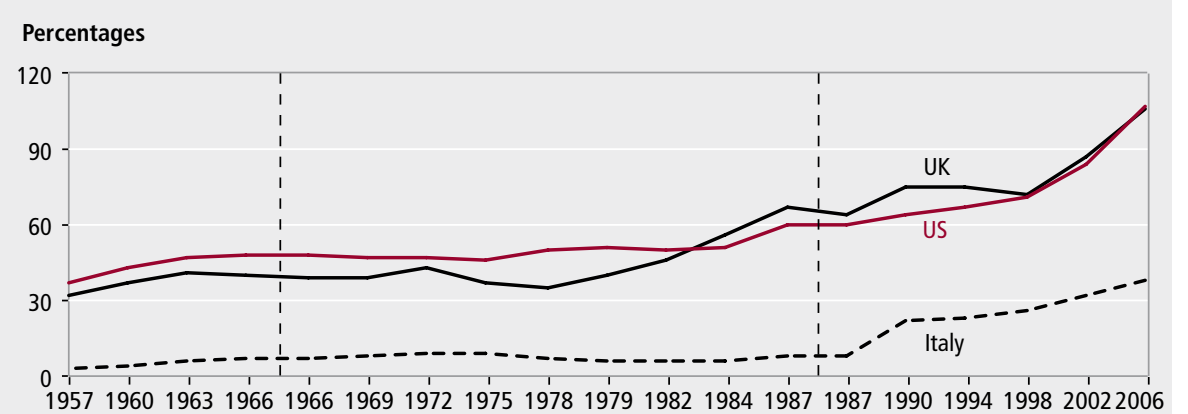

\section{Important structural differences} between the three countries The graphs in Figure 5 highlight the very dynamic financial structures in all the countries under analysis. In the UK, US and Italy, the last 50 years have witnessed the following common trends:

- a strong increase in the holding of equities and long-term instruments, such as life insurance and pension funds, at the expenses of deposits

- indirect participation in the financial markets via mutual funds and retirement products has increased significantly

- in spite of this revolution, the direct holding of shares has remained fairly stable in percentage terms

- safe instruments are less important than they were in the $1980 \mathrm{~s}$

Still, significant differences between the countries persist in the mix of financial instruments. Despite the common trend away from safety towards managed and long-term assets, there are important structural differences between the three countries:

- the UK presents the highest level of long-term investment (life insurance and pensions)

- the US is characterised by the importance of direct investment in shares and other equity

- safe instruments still make up around 40 per cent of household financial wealth in Italy; as expected, they are less important in the US and the UK

- Italy stands out for the importance of fixed income securities and a well below average share of long-term products

The main peculiarities of the UK financial structure can be summed up as follows:

- a lower portion of safe assets (currency, deposits, bonds) compared with the Italian asset mix, but higher than the US

- the UK presents a lower share of equities

- a large share of long-term investments such as pension funds and life insurance

Trends in liabilities: a massive rise in debt since the 1980s

Figure 6 shows household financial liabilities as a percentage of GDP in the countries under analysis. The ratio for both the US and UK began at 30 per cent and rose steadily through the 1980 s, quickening pace from the 1990s to reach GDP levels in 2006.

Such rapid growth in debt, accelerating especially in recent years in all three countries, should be viewed in the context of historically low interest rates which created an incentive for households to borrow, driving mortgages as well as consumer credit.

Despite the recent increases, Italian households still have low levels of debt (38 per cent of GDP), showing a stable and low ratio throughout the period (averaging 10 per cent). 


\section{Conclusion}

The methodology for reconstructing longterm time series for UK financial accounts was outlined.

During the reconstruction, good results were obtained regarding the sector breakdown of national wealth. As regards the instrumental breakdown, a good correspondence between the old and new time series for currency and deposits, mutual funds, life insurance and pension funds was found, but some problems emerged with miscellaneous instruments which have come to include shares, securities and loans.

Given the fair degree of continuity for the household sector, it was decided to extend the time series back to 1957 using earlier CSO figures for the period 1957 to 1978.

It is hoped new prospects for empirical research have been opened.

From the preliminary findings many interesting questions concerning financial accounts time series remain to be explained:

- which are the main determinants of financial asset growth?

- compared with other countries, UK households are more oriented towards longer-term assets. Are the other EU countries going to converge towards an Anglo-Saxon structure?

- a massive increase in debt has been witnessed since the 1980s, but in the light of the latest events, what could be the future trend in the liabilities side?

\section{Notes}

1 This work is part of a joint project between the OECD, Pioneer Investments Economic Research, ONS and the Bank of England.

2 CSO was a British government department charged with the collection and publication of economic statistics for the UK. It preceded ONS.

3 The financial balance sheet shows the financial assets held and the liabilities outstanding at a particular point in time. The balancing item of the financial balance sheet is net financial assets. Net financial assets is the result of cumulative revaluation, other changes in volume of financial assets and net lending/net borrowing (Manual on Sources and Methods for the Compilation of ESA95 Financial Accounts, Eurostat 2002).

4 The household sector is similar to, but not identical to, the previous personal sector. Sole traders as unincorporated businesses continue to be recorded here since their accounts are not separable from those of households. Partnerships are now classified to nonfinancial corporations (S11) or financial corporations (S12). Life insurance assurance and pension funds' income and expenditure were previously recorded in the personal sector. They are now recorded with the insurance corporations and pension funds' subsector (S125).

\section{ACKNOWLEDGEMENTS}

Special thanks go to Daniele Fano, Head of Economic Research in Pioneer Global Asset Management and Stuart Brown of ONS and also to Chris Wright and Stephen Sabine of the Bank of England, Riccardo de Bonis of the Bank of Italy, and Michael Rizzo of ONS, who actively promoted this project. Many thanks also go to Michelle ChavoixMannato of the OECD who has been part of the project since its inception, Milena Georgieva and Giuliana Maestrelli from Pioneer Investments Economic Research, and Michael Tucker of ONS for his support. This article describes research in progress. The author takes full responsibility for the views expressed and for the contents.

\section{CONTACT}

凶elmr@ons.gsi.gov.uk

\section{REFERENCES}

Antoniewicz R, Bonci R, Generale A, Marchese G, Neri A, Maser $K$ and $O$ 'Hagan $P$ (2005), Household Wealth: Comparing Micro and Macro Data in Canada, Italy and United States, paper presented at the International Conference on 'Construction and Usage of Comparable Microdata on Wealth', Luxembourg Wealth Study, Perugia, January 2005.

Babeau A and Sbano T (2002), Household Wealth in the Financial Accounts of Europe, the United States and Japan, OECD, available at

www.savingsandwealth.com.

Bank of England (1972) 'National balance sheets a new analytical tool', Bank of England Quarterly Bulletin.

Bartiloro L, De Bonis R, Generale A and Longhi I (2007) The financial structures of the leading industrial countries: a medium term analysis, in Bank of Italy (2007).

Bonci R and Coletta M (2005), Italy's Financial Accounts since 1950, Bank of Italy (2007).
Bonci R and Coletta M (2007), Italy's Financial Accounts since 1950, in Bank of Italy (2007).

De Bonis R (2007), Italy's Financial Wealth and Debt from 1950 to 2004, in Bank of Italy (2007).

De Bonis R and Gigliobianco A (2007) The Origins of Financial Accounts in the United States and Italy: Copeland, Baffi and the Institutions, in Bank of Italy (2007).

Fano D, and Sbano T (2007) "I portafogli delle famiglie 1995-2004 e la previdenza nei principali paesi OCSE. Primi segnali di convergenza verso veicoli a più lungo termine?", Quaderni Europei sul nuovo Welfare.

Fano D (2005) Assessing risk in household portfolios: progress and open issues at the macro and micro/survey level, Luxembourg Wealth Study.

Massaro R (2004) Household's financial assets and liabilities in Europe, Eurostat.

Office for National Statistics (1978) 'Personal sector balance sheets', Economic Trends 291, January 1978.

Office for National Statistics, Financial Statistics 214, February 1980, Supplementary Table C.

Pettigrew C W 'National and sector balance sheets for the United Kingdom', Economic Trends, November 1980.

Reid D J 'National and sector balance sheet'. Statistical News No. 35, November 1976.

Revell J 'The Wealth of the Nation', Cambridge University Press (1967).

Roe A R 'The Financial Interdependence of the Economy 1957-1966', Chapman and Hall (1971).

Schmidt R H, Hacketal A and Tyrell M (1999) Disintermediation and the role of banks in Europe: an international comparison, Journal of Financial Intermediation. 


\section{APPENDIX}

In the conversion table, an attempt has been made to illustrate the correspondence of instruments between the new and the old classification.

An unequivocal correspondence between the two classifications cannot be obtained. In particular, it was difficult to arrive at a clean split between 'securities other than shares' and 'shares and other equity' and between 'loans' and 'securities other than shares'. The main problems concern the following unambiguous items of the previous classification:

- miscellaneous domestic instruments including domestic securities, loans, mutual funds and trade credits

- overseas direct and other investments in securities, and miscellaneous overseas instruments including currency and deposits, securities other than shares, loans and mutual funds

- miscellaneous instruments including currency and deposits, securities, loans and trade credits

- UK company securities, primarily made up of securities and mutual funds

- overseas securities including securities and loans

- public corporation debt and local authority debt including loans and securities

To answer these problems, a specific approach for each sector and instrument was taken.

Table A1

\section{The conversion table}

\begin{tabular}{|c|c|}
\hline & New classification \\
\hline Financial assets & $\mathrm{F}$ \\
\hline Notes and coins & F2 \\
\hline Sterling treasury bills & F3 \\
\hline British government securities & F3 \\
\hline National savings & $\mathrm{F} 2$ \\
\hline Tax instruments & $\mathrm{F} 2$ \\
\hline Net government indebtedness banking department & F4 \\
\hline Northern Ireland central government debt & F3-F4 (F4) \\
\hline Government liabilities under exchange cover scheme & F4 \\
\hline \multicolumn{2}{|l|}{ Other public sector financing: } \\
\hline Non-marketable debt & F4 \\
\hline Short term assets & F4 \\
\hline Issue department's transactions in bills & F3 \\
\hline Government foreign currency debt & F3-F4 \\
\hline Other government overseas financing & F4 \\
\hline Official reserves & $\mathrm{F} 1$ \\
\hline Local authority debt & F3-F4 \\
\hline \multicolumn{2}{|l|}{ Public corporation debt } \\
\hline Foreign currency & F3-F4 \\
\hline Sterling & F3-F4 \\
\hline \multicolumn{2}{|l|}{ Deposits with banks } \\
\hline Sterling other & $\mathrm{F} 2$ \\
\hline Sterling & $\mathrm{F} 2$ \\
\hline Deposits with building societies & $\mathrm{F} 2$ \\
\hline Deposits with other financial institutions & $\mathrm{F} 2$ \\
\hline \multicolumn{2}{|l|}{ Bank lending (excluding public sector) } \\
\hline Foreign currency & F4 \\
\hline Sterling & F4 \\
\hline Credit extended by retailers & F4 \\
\hline \multicolumn{2}{|l|}{ Identified trade credit } \\
\hline Domestic & $\mathrm{F} 7$ \\
\hline Import export & $\mathrm{F} 7$ \\
\hline \multicolumn{2}{|l|}{ Loans for house purchase: } \\
\hline Building societies & F4 \\
\hline Other & F4 \\
\hline Other public sector lending & F4 F3 \\
\hline Other lending by financial institutions & F4 \\
\hline Unit trust & F5 \\
\hline UK company securities & F5 F3 \\
\hline Overseas securities & F5 F4 \\
\hline Life insurance and pension funds & F6 \\
\hline Miscellaneous domestic instrument abroad & F3 F4 F5 F7 \\
\hline Overseas direct and other investment in UK & F2 F3 F4 F4 \\
\hline Miscellaneous overseas instruments & F2 F3 F4 F5 \\
\hline Miscellaneous instruments & F2 F3 F4 F6 \\
\hline Direct and other investment abroad & F2 F3 F4 F7 \\
\hline Accruals adjustments & F7 \\
\hline
\end{tabular}


STATISTICAL ANNEX

Households - assets

\begin{tabular}{|c|c|c|c|c|c|c|c|}
\hline & $\begin{array}{r}\text { Total financial } \\
\text { assets }\end{array}$ & $\begin{array}{r}\text { Currency and } \\
\text { deposits }\end{array}$ & $\begin{array}{r}\text { Securities other } \\
\text { than shares }\end{array}$ & Loans & $\begin{array}{r}\text { Shares and } \\
\text { other equities }\end{array}$ & $\begin{array}{r}\text { Insurance technical } \\
\text { reserves }\end{array}$ & $\begin{array}{r}\mathrm{f} \text { billior } \\
\text { Other accounts } \\
\text { receivable }\end{array}$ \\
\hline 1957 & 43 & 14 & 4 & & 11 & 10 & 4 \\
\hline 1958 & 50 & 15 & 5 & & 15 & 11 & 4 \\
\hline 1959 & 59 & 16 & 5 & & 22 & 12 & 5 \\
\hline 1960 & 58 & 17 & 4 & & 20 & 13 & 5 \\
\hline 1961 & 62 & 17 & 5 & & 22 & 14 & 5 \\
\hline 1962 & 65 & 18 & 5 & & 22 & 15 & 5 \\
\hline 1963 & 70 & 19 & 5 & & 23 & 16 & 5 \\
\hline 1964 & 69 & 21 & 5 & & 20 & 18 & 6 \\
\hline 1965 & 73 & 22 & 5 & & 21 & 19 & 6 \\
\hline 1966 & 73 & 25 & 5 & & 21 & 15 & 7 \\
\hline 1967 & 79 & 19 & 11 & & 27 & 16 & 6 \\
\hline 1968 & 88 & 19 & 11 & & 33 & 18 & 6 \\
\hline 1969 & 91 & 30 & 5 & & 29 & 20 & 8 \\
\hline 1970 & 88 & 21 & 13 & & 27 & 20 & 6 \\
\hline 1971 & 106 & 23 & 17 & & 36 & 24 & 6 \\
\hline 1972 & 127 & 41 & 7 & & 42 & 29 & 9 \\
\hline 1973 & 116 & 30 & 21 & & 32 & 28 & 7 \\
\hline 1974 & 105 & 33 & 21 & & 18 & 25 & 8 \\
\hline 1975 & 140 & 58 & 8 & & 27 & 34 & 13 \\
\hline 1976 & 147 & 37 & 33 & & 29 & 37 & 10 \\
\hline 1977 & 171 & 73 & 14 & & 33 & 52 & 14 \\
\hline 1978 & 205 & 85 & 12 & & 33 & 61 & 15 \\
\hline 1979 & 251 & 99 & 18 & 3 & 33 & 82 & 17 \\
\hline 1980 & 304 & 116 & 20 & 3 & 39 & 107 & 20 \\
\hline 1981 & 345 & 138 & 21 & 3 & 39 & 123 & 21 \\
\hline 1982 & 413 & 149 & 25 & 3 & 50 & 162 & 24 \\
\hline 1983 & 485 & 166 & 27 & 2 & 61 & 200 & 28 \\
\hline 1984 & 568 & 188 & 25 & 2 & 73 & 246 & 34 \\
\hline 1985 & 645 & 209 & 26 & 2 & 80 & 291 & 38 \\
\hline 1986 & 773 & 229 & 30 & 2 & 115 & 358 & 39 \\
\hline 1987 & 840 & 250 & 24 & 6 & 135 & 389 & 36 \\
\hline 1988 & 951 & 289 & 21 & 6 & 142 & 453 & 40 \\
\hline 1989 & 1,144 & 327 & 19 & 6 & 177 & 566 & 48 \\
\hline 1990 & 1,191 & 360 & 21 & 6 & 221 & 530 & 54 \\
\hline 1991 & 1,322 & 385 & 22 & 5 & 234 & 616 & 60 \\
\hline 1992 & 1,471 & 409 & 31 & 5 & 262 & 703 & 61 \\
\hline 1993 & 1,755 & 423 & 33 & 5 & 335 & 896 & 63 \\
\hline 1994 & 1,721 & 437 & 34 & 5 & 331 & 849 & 65 \\
\hline 1995 & 1,958 & 469 & 41 & 5 & 380 & 995 & 67 \\
\hline 1996 & 2,078 & 494 & 41 & 6 & 401 & 1,069 & 67 \\
\hline 1997 & 2,471 & 535 & 43 & 6 & 516 & 1,301 & 69 \\
\hline 1998 & 2,649 & 567 & 46 & 7 & 533 & 1,425 & 71 \\
\hline 1999 & 3,126 & 601 & 47 & 7 & 733 & 1,663 & 76 \\
\hline 2000 & 3,117 & 635 & 47 & 7 & 712 & 1,634 & 83 \\
\hline 2001 & 2,922 & 681 & 46 & 7 & 537 & 1,565 & 86 \\
\hline 2002 & 2,681 & 731 & 46 & 7 & 393 & 1,419 & 85 \\
\hline 2003 & 2,930 & 793 & 48 & 7 & 448 & 1,544 & 90 \\
\hline 2004 & 3,153 & 855 & 50 & 7 & 502 & 1,641 & 98 \\
\hline 2005 & 3,591 & 921 & 43 & 7 & 586 & 1,932 & 102 \\
\hline 2006 & 3,846 & 997 & 35 & 7 & 590 & 2,111 & 106 \\
\hline
\end{tabular}

Note:

Data are provisional. 
Households - liabilities

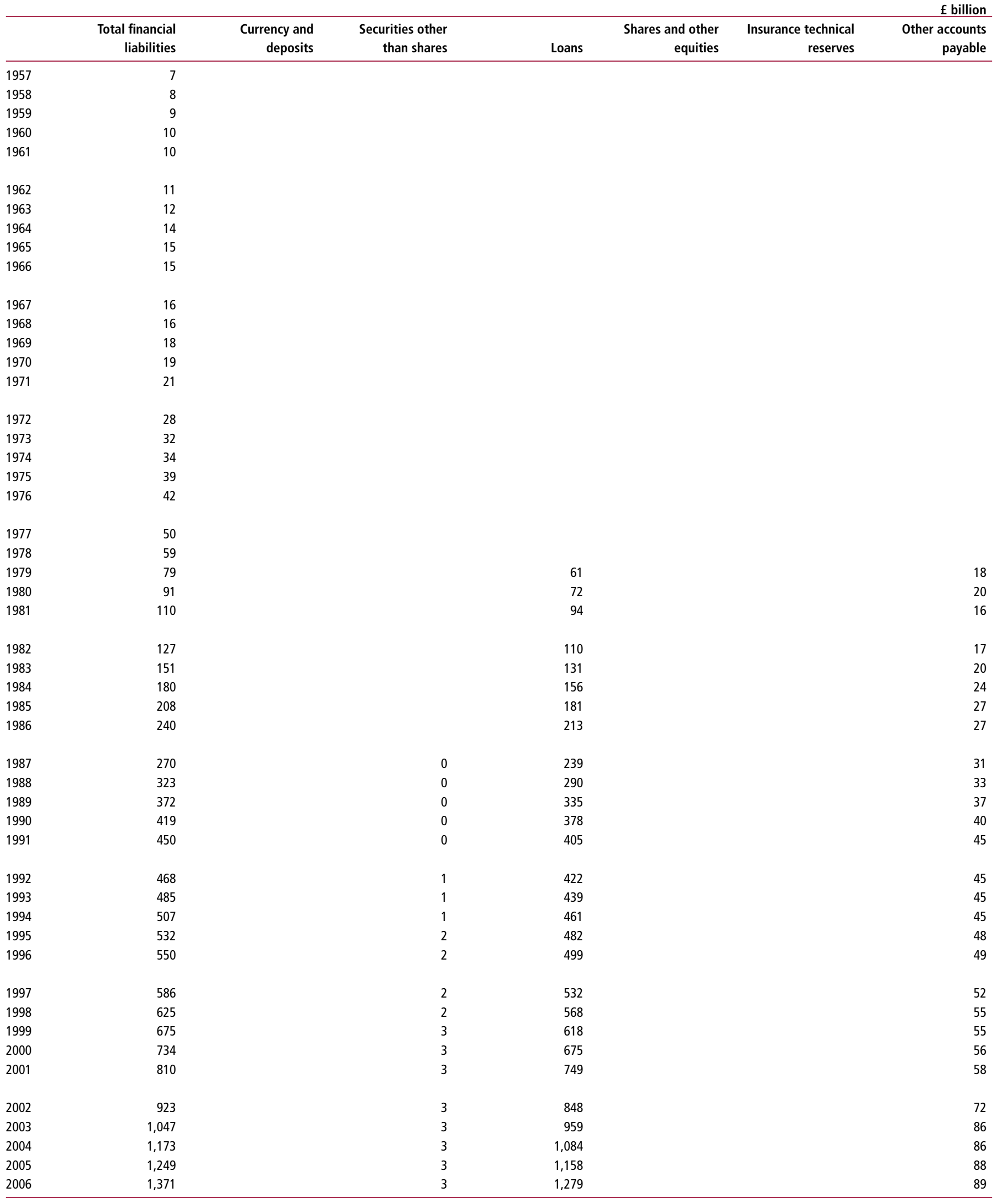


Non-financial corporations - assets

f billion

\begin{tabular}{|c|c|c|c|c|c|c|c|}
\hline & $\begin{array}{r}\text { Total financial } \\
\text { assets }\end{array}$ & $\begin{array}{r}\text { Currency and } \\
\text { deposits }\end{array}$ & $\begin{array}{r}\text { Securities other } \\
\text { than shares }\end{array}$ & Loans & $\begin{array}{r}\text { Shares and } \\
\text { other equities }\end{array}$ & $\begin{array}{r}\text { Insurance technical } \\
\text { reserves }\end{array}$ & $\begin{array}{r}£ \text { billion } \\
\text { Other accounts } \\
\text { receivable }\end{array}$ \\
\hline 1979 & 128 & 17 & 33 & 8 & 15 & & 55 \\
\hline 1980 & 145 & 20 & 30 & 10 & 25 & & 59 \\
\hline 1981 & 174 & 26 & 40 & 15 & 29 & & 64 \\
\hline 1982 & 199 & 30 & 47 & 16 & 37 & & 69 \\
\hline 1983 & 228 & 37 & 52 & 19 & 43 & & 76 \\
\hline 1984 & 241 & 42 & 67 & 9 & 37 & & 85 \\
\hline 1985 & 251 & 46 & 62 & 10 & 42 & & 91 \\
\hline 1986 & 285 & 56 & 69 & 11 & 56 & & 92 \\
\hline 1987 & 339 & 83 & 128 & 34 & 118 & 8 & 86 \\
\hline 1988 & 390 & 90 & 152 & 49 & 139 & 9 & 90 \\
\hline 1989 & 445 & 109 & 173 & 64 & 160 & 9 & 89 \\
\hline 1990 & 422 & 122 & 144 & 58 & 130 & 10 & 89 \\
\hline 1991 & 438 & 128 & 153 & 58 & 136 & 11 & 88 \\
\hline 1992 & 462 & 129 & 175 & 59 & 159 & 9 & 90 \\
\hline 1993 & 501 & 147 & 191 & 62 & 169 & 10 & 91 \\
\hline 1994 & 520 & 155 & 199 & 66 & 174 & 8 & 92 \\
\hline 1995 & 566 & 166 & 224 & 76 & 194 & 9 & 92 \\
\hline 1996 & 591 & 181 & 227 & 80 & 201 & 13 & 91 \\
\hline 1997 & 645 & 203 & 252 & 86 & 226 & 11 & 92 \\
\hline 1998 & 745 & 209 & 311 & 120 & 282 & 12 & 93 \\
\hline 1999 & 954 & 232 & 479 & 142 & 445 & 11 & 91 \\
\hline 2000 & 1,207 & 271 & 659 & 146 & 598 & 15 & 117 \\
\hline 2001 & 1,209 & 292 & 629 & 159 & 563 & 12 & 117 \\
\hline 2002 & 1,276 & 332 & 635 & 178 & 571 & 13 & 117 \\
\hline 2003 & 1,389 & 389 & 690 & 173 & 622 & 16 & 120 \\
\hline 2004 & 1,456 & 447 & 675 & 194 & 608 & 17 & 125 \\
\hline 2005 & 1,634 & 525 & 56 & 215 & 683 & 17 & 137 \\
\hline 2006 & 1,700 & 579 & 79 & 195 & 685 & 18 & 143 \\
\hline
\end{tabular}




\section{Non-financial corporations - liabilities}

$\mathrm{f}$ billion

\begin{tabular}{|c|c|c|c|c|c|c|c|}
\hline & $\begin{array}{r}\text { Total financial } \\
\text { liabilities }\end{array}$ & $\begin{array}{r}\text { Currency and } \\
\text { deposits }\end{array}$ & $\begin{array}{r}\text { Securities other } \\
\text { than shares }\end{array}$ & Loans & $\begin{array}{r}\text { Shares and } \\
\text { other equities }\end{array}$ & $\begin{array}{r}\text { Insurance technical } \\
\text { reserves }\end{array}$ & $\begin{array}{r}\text { Other accounts } \\
\text { payable }\end{array}$ \\
\hline 1979 & 223 & & 1 & 62 & 111 & & 50 \\
\hline 1980 & 254 & & 1 & 70 & 129 & & 54 \\
\hline 1981 & 288 & & 3 & 83 & 144 & & 59 \\
\hline 1982 & 334 & & 5 & 85 & 180 & & 63 \\
\hline 1983 & 386 & & 5 & 92 & 218 & & 71 \\
\hline 1984 & 448 & & 6 & 101 & 264 & & 77 \\
\hline 1985 & 498 & & 7 & 104 & 306 & & 81 \\
\hline 1986 & 601 & & 7 & 113 & 376 & & 104 \\
\hline 1987 & 714 & & 2 & 191 & 417 & & 104 \\
\hline 1988 & 828 & & 5 & 244 & 470 & & 110 \\
\hline 1989 & 1,023 & & 6 & 315 & 588 & & 114 \\
\hline 1990 & 1,042 & & 52 & 335 & 539 & & 115 \\
\hline 1991 & 1,156 & & 62 & 340 & 637 & & 117 \\
\hline 1992 & 1,251 & & 63 & 352 & 718 & & 117 \\
\hline 1993 & 1,426 & & 77 & 351 & 878 & & 121 \\
\hline 1994 & 1,388 & & 80 & 339 & 843 & & 126 \\
\hline 1995 & 1,567 & & 98 & 363 & 980 & & 127 \\
\hline 1996 & 1,678 & & 102 & 377 & 1,073 & & 127 \\
\hline 1997 & 1,922 & & 117 & 409 & 1,266 & & 129 \\
\hline 1998 & 2,161 & & 142 & 460 & 1,428 & & 129 \\
\hline 1999 & 2,712 & & 179 & 528 & 1,870 & & 133 \\
\hline 2000 & 2,844 & & 224 & 600 & 1,880 & & 137 \\
\hline 2001 & 2,655 & & 235 & 673 & 1,606 & & 139 \\
\hline 2002 & 2,384 & & 263 & 750 & 1,229 & & 140 \\
\hline 2003 & 2,639 & & 281 & 795 & 1,419 & & 142 \\
\hline 2004 & 2,852 & & 294 & 875 & 1,546 & & 147 \\
\hline 2005 & 3,326 & & 344 & 1,001 & 1,827 & & 154 \\
\hline 2006 & 3,659 & & 382 & 1,123 & 1,999 & & 156 \\
\hline
\end{tabular}


Financial corporations - assets

£ billion

\begin{tabular}{|c|c|c|c|c|c|c|c|}
\hline & $\begin{array}{r}\text { Total financial } \\
\text { assets }\end{array}$ & $\begin{array}{r}\text { Currency and } \\
\text { deposits }\end{array}$ & $\begin{array}{r}\text { Securities other } \\
\text { than shares }\end{array}$ & Loans & $\begin{array}{r}\text { Shares and } \\
\text { other equities }\end{array}$ & $\begin{array}{r}\text { Insurance technical } \\
\text { reserves }\end{array}$ & $\begin{array}{r}£ \text { billion } \\
\text { Other accounts } \\
\text { receivable }\end{array}$ \\
\hline 1979 & 407 & 82 & 37 & 234 & 52 & & 3 \\
\hline 1980 & 487 & 97 & 46 & 271 & 71 & & 3 \\
\hline 1981 & 665 & 131 & 45 & 396 & 91 & & 3 \\
\hline 1982 & 834 & 166 & 63 & 476 & 127 & & 3 \\
\hline 1983 & 975 & 177 & 72 & 552 & 171 & & 3 \\
\hline 1984 & 1,224 & 249 & 82 & 666 & 224 & & 4 \\
\hline 1985 & 1,289 & 258 & 91 & 662 & 275 & & 4 \\
\hline 1986 & 1,546 & 295 & 95 & 781 & 373 & & 2 \\
\hline 1987 & 1,588 & 517 & 217 & 502 & 338 & 1 & 13 \\
\hline 1988 & 1,793 & 554 & 227 & 605 & 392 & 1 & 14 \\
\hline 1989 & 2,191 & 651 & 262 & 737 & 524 & 1 & 16 \\
\hline 1990 & 2,214 & 656 & 308 & 806 & 434 & 1 & 10 \\
\hline 1991 & 2,321 & 614 & 345 & 819 & 531 & 1 & 11 \\
\hline 1992 & 2,652 & 735 & 432 & 864 & 607 & 1 & 12 \\
\hline 1993 & 3,073 & 795 & 585 & 870 & 810 & 1 & 13 \\
\hline 1994 & 3,070 & 847 & 547 & 902 & 759 & 2 & 14 \\
\hline 1995 & 3,516 & 966 & 639 & 1,002 & 889 & 2 & 18 \\
\hline 1996 & 3,857 & 1,039 & 716 & 1,101 & 980 & 2 & 20 \\
\hline 1997 & 4,559 & 1,282 & 845 & 1,226 & 1,179 & 2 & 24 \\
\hline 1998 & 4,883 & 1,326 & 950 & 1,292 & 1,289 & 1 & 26 \\
\hline 1999 & 5,390 & 1,311 & 1,025 & 1,393 & 1,633 & 2 & 27 \\
\hline 2000 & 6,005 & 1,614 & 1,111 & 1,601 & 1,648 & 2 & 29 \\
\hline 2001 & 6,357 & 1,800 & 1,183 & 1,763 & 1,578 & 1 & 31 \\
\hline 2002 & 6,395 & 1,908 & 1,236 & 1,911 & 1,290 & 1 & 49 \\
\hline 2003 & 7,376 & 2,290 & 1,308 & 2,175 & 1,535 & 2 & 66 \\
\hline 2004 & 8,335 & 2,559 & 1,449 & 2,519 & 1,738 & 2 & 67 \\
\hline 2005 & 9,932 & 3,209 & 1,678 & 2,878 & 2,095 & 2 & 70 \\
\hline 2006 & 11,248 & 3,694 & 1,877 & 3,234 & 2,369 & 2 & 72 \\
\hline
\end{tabular}


Financial corporations - liabilities

\begin{tabular}{|c|c|c|c|c|c|c|c|}
\hline & $\begin{array}{r}\text { Total financial } \\
\text { liabilities }\end{array}$ & $\begin{array}{r}\text { Currency and } \\
\text { deposits }\end{array}$ & $\begin{array}{r}\text { Securities other } \\
\text { than shares }\end{array}$ & Loans & $\begin{array}{r}\text { Shares and } \\
\text { other equities }\end{array}$ & $\begin{array}{r}\text { Insurance technical } \\
\text { reserves }\end{array}$ & $\begin{array}{r}f \text { billion } \\
\begin{array}{r}\text { Other accounts } \\
\text { payable }\end{array}\end{array}$ \\
\hline 1979 & 430 & 306 & & 8 & 27 & 78 & 11 \\
\hline 1980 & 519 & 358 & & 9 & 38 & 102 & 12 \\
\hline 1981 & 682 & 490 & 1 & 15 & 45 & 118 & 13 \\
\hline 1982 & 842 & 603 & 2 & 21 & 47 & 156 & 13 \\
\hline 1983 & 985 & 687 & 2 & 27 & 62 & 194 & 13 \\
\hline 1984 & 1,223 & 842 & 3 & 39 & 85 & 239 & 15 \\
\hline 1985 & 1,284 & 838 & 4 & 39 & 103 & 283 & 16 \\
\hline 1986 & 1,534 & 971 & 4 & 52 & 140 & 350 & 18 \\
\hline 1987 & 1,626 & 883 & 122 & 76 & 137 & 400 & 7 \\
\hline 1988 & 1,837 & 975 & 140 & 93 & 157 & 466 & 7 \\
\hline 1989 & 2,252 & 1,153 & 164 & 137 & 206 & 581 & 10 \\
\hline 1990 & 2,297 & 1,206 & 201 & 145 & 186 & 547 & 12 \\
\hline 1991 & 2,386 & 1,189 & 202 & 157 & 191 & 635 & 13 \\
\hline 1992 & 2,718 & 1,351 & 218 & 191 & 224 & 723 & 12 \\
\hline 1993 & 3,181 & 1,426 & 222 & 284 & 322 & 915 & 11 \\
\hline 1994 & 3,176 & 1,512 & 243 & 242 & 302 & 866 & 11 \\
\hline 1995 & 3,686 & 1,685 & 281 & 317 & 374 & 1,016 & 14 \\
\hline 1996 & 4,050 & 1,753 & 333 & 422 & 427 & 1,100 & 14 \\
\hline 1997 & 4,882 & 2,061 & 382 & 497 & 595 & 1,331 & 16 \\
\hline 1998 & 5,240 & 2,201 & 410 & 494 & 663 & 1,454 & 18 \\
\hline 1999 & 5,794 & 2,218 & 487 & 544 & 830 & 1,690 & 23 \\
\hline 2000 & 6,442 & 2,614 & 570 & 646 & 921 & 1,662 & 29 \\
\hline 2001 & 6,762 & 2,866 & 637 & 752 & 885 & 1,591 & 32 \\
\hline 2002 & 6,728 & 3,066 & 686 & 749 & 745 & 1,447 & 34 \\
\hline 2003 & 7,668 & 3,552 & 766 & 855 & 880 & 1,573 & 42 \\
\hline 2004 & 8,589 & 4,023 & 878 & 989 & 979 & 1,671 & 49 \\
\hline 2005 & 10,232 & 4,719 & 1,053 & 1,301 & 1,143 & 1,966 & 51 \\
\hline 2006 & 11,518 & 5,374 & 1,214 & 1,401 & 1,327 & 2,147 & 54 \\
\hline
\end{tabular}




\section{Government - assets}

f billion

\begin{tabular}{|c|c|c|c|c|c|c|c|}
\hline & $\begin{array}{r}\text { Total financial } \\
\text { assets }\end{array}$ & $\begin{array}{r}\text { Currency and } \\
\text { deposits }\end{array}$ & $\begin{array}{r}\text { Securities other } \\
\text { than shares }\end{array}$ & Loans & $\begin{array}{r}\text { Shares and } \\
\text { other equities }\end{array}$ & $\begin{array}{r}\text { Insurance technical } \\
\text { reserves }\end{array}$ & $\begin{array}{r}£ \text { billion } \\
\text { Other accounts } \\
\text { receivable }\end{array}$ \\
\hline 1979 & 78 & 14 & 0 & 46 & 7 & 0 & 11 \\
\hline 1980 & 85 & 15 & 0 & 50 & 7 & 0 & 13 \\
\hline 1981 & 88 & 13 & 3 & 48 & 5 & 0 & 19 \\
\hline 1982 & 95 & 15 & 8 & 51 & 5 & 0 & 17 \\
\hline 1983 & 104 & 15 & 7 & 56 & 6 & 0 & 20 \\
\hline 1984 & 119 & 15 & 10 & 57 & 17 & 0 & 20 \\
\hline 1985 & 127 & 16 & 11 & 62 & 16 & 0 & 22 \\
\hline 1986 & 137 & 22 & 12 & 67 & 15 & 0 & 21 \\
\hline 1987 & 144 & 13 & 21 & 69 & 15 & 0 & 25 \\
\hline 1988 & 157 & 16 & 24 & 77 & 14 & 0 & 26 \\
\hline 1989 & 166 & 18 & 21 & 83 & 15 & 0 & 29 \\
\hline 1990 & 159 & 15 & 23 & 80 & 11 & 0 & 30 \\
\hline 1991 & 164 & 13 & 27 & 79 & 13 & 1 & 32 \\
\hline 1992 & 160 & 16 & 29 & 72 & 13 & 1 & 30 \\
\hline 1993 & 165 & 21 & 29 & 70 & 12 & 1 & 32 \\
\hline 1994 & 155 & 18 & 29 & 66 & 8 & 1 & 33 \\
\hline 1995 & 157 & 25 & 24 & 67 & 6 & 1 & 35 \\
\hline 1996 & 145 & 24 & 20 & 60 & 3 & 1 & 38 \\
\hline 1997 & 150 & 27 & 15 & 61 & 3 & 1 & 42 \\
\hline 1998 & 147 & 25 & 17 & 61 & 3 & 1 & 39 \\
\hline 1999 & 148 & 26 & 13 & 63 & 5 & 1 & 39 \\
\hline 2000 & 181 & 44 & 25 & 67 & 4 & 1 & 40 \\
\hline 2001 & 171 & 32 & 23 & 70 & 4 & 1 & 41 \\
\hline 2002 & 168 & 30 & 24 & 70 & 4 & 1 & 39 \\
\hline 2003 & 171 & 32 & 21 & 69 & 5 & 1 & 43 \\
\hline 2004 & 178 & 34 & 22 & 71 & 5 & 1 & 45 \\
\hline 2005 & 190 & 33 & 25 & 76 & 6 & 1 & 50 \\
\hline 2006 & 200 & 36 & 27 & 80 & 6 & 1 & 51 \\
\hline
\end{tabular}




\section{Government - liabilities}

$\mathrm{f}$ billion

\begin{tabular}{|c|c|c|c|c|c|c|c|}
\hline & $\begin{array}{r}\text { Total financial } \\
\text { liabilities }\end{array}$ & $\begin{array}{r}\text { Currency and } \\
\text { deposits }\end{array}$ & $\begin{array}{r}\text { Securities other } \\
\text { than shares }\end{array}$ & Loans & $\begin{array}{r}\text { Shares and } \\
\text { other equities }\end{array}$ & $\begin{array}{r}\text { Insurance technical } \\
\text { reserves }\end{array}$ & $\begin{array}{r}£ \text { billion } \\
\text { Other accounts } \\
\text { payable }\end{array}$ \\
\hline 1979 & 124 & 23 & 49 & 41 & 2 & 0 & 5 \\
\hline 1980 & 142 & 25 & 62 & 42 & 2 & 0 & 6 \\
\hline 1981 & 151 & 32 & 63 & 41 & 2 & 5 & 7 \\
\hline 1982 & 182 & 37 & 88 & 41 & 2 & 6 & 8 \\
\hline 1983 & 200 & 41 & 99 & 43 & 2 & 6 & 9 \\
\hline 1984 & 211 & 46 & 107 & 45 & 3 & 0 & 11 \\
\hline 1985 & 238 & 49 & 117 & 49 & 3 & 8 & 12 \\
\hline 1986 & 256 & 52 & 126 & 54 & 3 & 8 & 13 \\
\hline 1987 & 251 & 42 & 147 & 54 & 0 & 0 & 8 \\
\hline 1988 & 252 & 43 & 142 & 58 & 0 & 0 & 9 \\
\hline 1989 & 244 & 42 & 130 & 63 & 0 & 0 & 10 \\
\hline 1990 & 240 & 44 & 122 & 66 & 0 & 0 & 9 \\
\hline 1991 & 253 & 46 & 134 & 64 & 0 & 0 & 10 \\
\hline 1992 & 295 & 51 & 172 & 60 & 0 & 0 & 12 \\
\hline 1993 & 371 & 58 & 246 & 55 & 0 & 0 & 13 \\
\hline 1994 & 377 & 64 & 239 & 61 & 0 & 0 & 13 \\
\hline 1995 & 434 & 68 & 287 & 66 & 0 & 0 & 14 \\
\hline 1996 & 457 & 75 & 301 & 67 & 0 & 0 & 14 \\
\hline 1997 & 496 & 77 & 334 & 66 & 0 & 0 & 19 \\
\hline 1998 & 527 & 76 & 365 & 67 & 0 & 0 & 20 \\
\hline 1999 & 507 & 75 & 339 & 74 & 0 & 0 & 19 \\
\hline 2000 & 528 & 78 & 329 & 79 & 0 & 0 & 42 \\
\hline 2001 & 500 & 76 & 309 & 74 & 0 & 0 & 42 \\
\hline 2002 & 522 & 78 & 330 & 75 & 0 & 0 & 39 \\
\hline 2003 & 551 & 80 & 355 & 74 & 0 & 0 & 42 \\
\hline 2004 & 606 & 82 & 395 & 83 & 0 & 0 & 46 \\
\hline 2005 & 678 & 88 & 442 & 89 & 0 & 0 & 59 \\
\hline 2006 & 715 & 93 & 466 & 91 & 0 & 0 & 65 \\
\hline
\end{tabular}


Rest of the world - assets

f billion

\begin{tabular}{|c|c|c|c|c|c|c|c|}
\hline & $\begin{array}{r}\text { Total financial } \\
\text { assets }\end{array}$ & $\begin{array}{r}\text { Currency and } \\
\text { deposits }\end{array}$ & $\begin{array}{r}\text { Securities other } \\
\text { than shares }\end{array}$ & Loans & $\begin{array}{r}\text { Shares and } \\
\text { other equities }\end{array}$ & $\begin{array}{r}\text { Insurance technical } \\
\text { reserves }\end{array}$ & $\begin{array}{r}£ \text { billion } \\
\text { Other accounts } \\
\text { receivable }\end{array}$ \\
\hline 1979 & 198 & 134 & 30 & 14 & 12 & 0 & 7 \\
\hline 1980 & 229 & 153 & 32 & 19 & 19 & 0 & 7 \\
\hline 1981 & 330 & 220 & 1 & 33 & 26 & 0 & 7 \\
\hline 1982 & 416 & 13 & 2 & 38 & 42 & 0 & 7 \\
\hline 1983 & 486 & 13 & 2 & 46 & 61 & 0 & 2 \\
\hline 1984 & 641 & 398 & 75 & 80 & 87 & 0 & 1 \\
\hline 1985 & 605 & 360 & 70 & 75 & 100 & 0 & 1 \\
\hline 1986 & 734 & 427 & 81 & 83 & 142 & 0 & 0 \\
\hline 1987 & 660 & 415 & 81 & 62 & 97 & 2 & 2 \\
\hline 1988 & 751 & 445 & 94 & 81 & 126 & 3 & 2 \\
\hline 1989 & 944 & 540 & 107 & 125 & 166 & 4 & 2 \\
\hline 1990 & 958 & 538 & 133 & 134 & 145 & 5 & 2 \\
\hline 1991 & 989 & 515 & 141 & 162 & 162 & 6 & 2 \\
\hline 1992 & 1,181 & 628 & 157 & 198 & 186 & 8 & 3 \\
\hline 1993 & 1,371 & 664 & 177 & 288 & 233 & 7 & 3 \\
\hline 1994 & 1,377 & 714 & 198 & 230 & 225 & 8 & 2 \\
\hline 1995 & 1,625 & 803 & 238 & 280 & 292 & 10 & 3 \\
\hline 1996 & 1,760 & 783 & 260 & 351 & 347 & 15 & 4 \\
\hline 1997 & 2,107 & 955 & 288 & 409 & 436 & 16 & 4 \\
\hline 1998 & 2,358 & 1,040 & 297 & 439 & 562 & 15 & 4 \\
\hline 1999 & 2,599 & 1,034 & 326 & 521 & 702 & 14 & 2 \\
\hline 2000 & 3,143 & 1,268 & 405 & 612 & 845 & 11 & 2 \\
\hline 2001 & 3,365 & 1,376 & 447 & 740 & 789 & 11 & 3 \\
\hline 2002 & 3,369 & 1,442 & 500 & 773 & 639 & 13 & 2 \\
\hline 2003 & 3,767 & 1,608 & 572 & 837 & 737 & 10 & 2 \\
\hline 2004 & 4,288 & 1,858 & 672 & 943 & 803 & 11 & 2 \\
\hline 2005 & 5,274 & 2,202 & 832 & 1,252 & 971 & 14 & 2 \\
\hline 2006 & 5,789 & 2,374 & 956 & 1,301 & 1,141 & 15 & 2 \\
\hline
\end{tabular}


Rest of the world - liabilities

\begin{tabular}{|c|c|c|c|c|c|c|c|}
\hline & $\begin{array}{r}\text { Total financial } \\
\text { liabilities }\end{array}$ & $\begin{array}{r}\text { Currency and } \\
\text { deposits }\end{array}$ & $\begin{array}{r}\text { Securities other } \\
\text { than shares }\end{array}$ & Loans & $\begin{array}{r}\text { Shares and } \\
\text { other equities }\end{array}$ & $\begin{array}{r}\text { Insurance technical } \\
\text { reserves }\end{array}$ & $\begin{array}{r}\text { Other accounts } \\
\text { payable }\end{array}$ \\
\hline 1979 & 184 & 108 & 4 & 34 & 32 & & 4 \\
\hline 1980 & 210 & 123 & 6 & 39 & 39 & & 4 \\
\hline 1981 & 298 & 184 & 6 & 58 & 43 & & 5 \\
\hline 1982 & 373 & 235 & 8 & 74 & 51 & & 5 \\
\hline 1983 & 434 & 277 & 8 & 88 & 57 & & 2 \\
\hline 1984 & 542 & 350 & 9 & 110 & 75 & & 1 \\
\hline 1985 & 519 & 321 & 12 & 101 & 91 & & 1 \\
\hline 1986 & 616 & 374 & 15 & 118 & 118 & & 0 \\
\hline 1987 & 704 & 348 & 82 & 113 & 148 & 0 & 13 \\
\hline 1988 & 795 & 371 & 92 & 132 & 186 & 0 & 13 \\
\hline 1989 & 991 & 444 & 123 & 163 & 248 & 0 & 14 \\
\hline 1990 & 941 & 436 & 123 & 159 & 216 & 0 & 8 \\
\hline 1991 & 982 & 417 & 153 & 156 & 248 & 0 & 9 \\
\hline 1992 & 1,189 & 507 & 211 & 176 & 285 & 0 & 10 \\
\hline 1993 & 1,397 & 560 & 299 & 170 & 358 & 0 & 10 \\
\hline 1994 & 1,397 & 589 & 269 & 168 & 359 & 0 & 11 \\
\hline 1995 & 1,607 & 670 & 305 & 205 & 416 & 0 & 11 \\
\hline 1996 & 1,700 & 689 & 327 & 229 & 441 & 0 & 14 \\
\hline 1997 & 2,049 & 860 & 383 & 285 & 507 & 0 & 14 \\
\hline 1998 & 2,237 & 886 & 419 & 330 & 589 & 0 & 12 \\
\hline 1999 & 2,541 & 907 & 437 & 359 & 834 & 0 & 4 \\
\hline 2000 & 3,116 & 1,139 & 524 & 431 & 1,018 & 0 & 4 \\
\hline 2001 & 3,304 & 1,241 & 581 & 490 & 989 & 0 & 4 \\
\hline 2002 & 3,330 & 1,298 & 587 & 512 & 927 & 0 & 6 \\
\hline 2003 & 3,720 & 1,475 & 612 & 581 & 1,045 & 0 & 8 \\
\hline 2004 & 4,175 & 1,644 & 685 & 714 & 1,122 & 0 & 9 \\
\hline 2005 & 5,130 & 2,080 & 793 & 878 & 1,371 & 0 & 9 \\
\hline 2006 & 5,520 & 2,213 & 909 & 923 & 1,465 & 0 & 10 \\
\hline
\end{tabular}

